Table 2

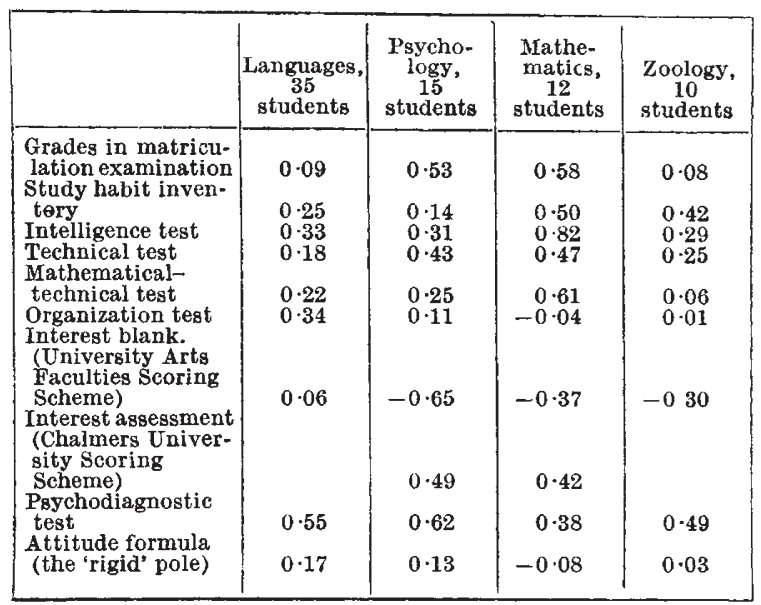

At the University of Technology the coefficients of validity in Table $\mathbf{3}$ were obtained.

It appears that the matriculation examination has a considerably higher prognostic value for these than for those at the University (arts faculties), probably because the courses at the former have to be followed closely and in many respects resemble pre-matriculation studies. For this reason, the matriculation examination can be considered as a job sample test.

A combination of the matriculation results and tests would form the most suitable instrument of prognosis for these students, provided that the
Table 3

\begin{tabular}{|l|c|}
\hline & 219 students \\
\hline Grades in matriculation examination & 0.67 \\
Study habit inventory & $0 \cdot 30$ \\
Inteligence test & 0.15 \\
Technical test & 0.22 \\
Mathematical-technical test & $0 \cdot 32$ \\
Organization test & 0.09 \\
Interest blank & 0.20 \\
Psychodiagnostic test & 0.22 \\
Attitude assessment (the 'rigid' pole) & 0.01 \\
Entrance qualifications (matriculation grades + & 0.52 \\
previous factory experience) & 0.77 \\
Best combination of six prognostic variables & \\
\hline
\end{tabular}

multiple regression calculation stands up to cross validation in a renewed investigation.

At the University of Economics the criterion used was the average result in all the subjects passed. The coefficients of validity were as shown in Table 4 .

\begin{tabular}{|l|c|}
\hline \multicolumn{2}{|c|}{ Table 4 } \\
\hline Grades in matriculation examination & 49 students \\
Study habit inventory & $0 \cdot 22$ \\
Intelligence test & $0 \cdot 46$ \\
Technical test & $0 \cdot 18$ \\
Mathematical-technical test & $0 \cdot 31$ \\
Organization test & $0 \cdot 34$ \\
Interest blank & $0 \cdot 18$ \\
Psychodiagnostic test & $0 \cdot 16$ \\
Attitude assessment & $0 \cdot 36$ \\
Best combination of seven prognostic variables & $0 \cdot 04$ \\
& $0 \cdot 77$ \\
\hline
\end{tabular}

The study habit inventory had the highest validity here, followed by Zulliger's psychodiagnostic test and the mathematical-technical test. The low validity of the matriculation result is worthy of note.

\title{
INDUSTRY AND GOVERNMENT IN CANADA
}

TN his Messel Lecture, "Industry and Government in Canada", before the Society of Chemical Industry at Montreal on September 15, the Rt. Hon. C. D. Howe, P.C., reviews changes in the responsibilities of government and the attitude of industry during the past fifty years. When he came to Canada as a graduate engineer in $1908, \mathrm{Mr}$. Howe said that most people regarded activities at Ottawa as remote and of very little personal concern. Now, an industrial revolution and relatively sudden highly scientific industrial and military developments, with the rise of the Welfare State, had transformed the scale and character of government administrative responsibility. While the population had grown from 6.5 million to 17 million, government expenditure had multiplied about twenty-five times and was now 5,272 million dollars a year. Mr. Howe believed that most Canadian business men to-day recognized that the public demanded services which only government could provide and that many of them not only tolerated government activity but also were prepared to admit that government action could promote the prosperity and welfare of the country. There had also been a similar improvement in the attitude of government towards business in Canada, and his experience as a Minister during 1935-57 led him to believe that the role of industry and commerce in society was better understood than it had been before.

Mr. Howe then referred to some changes in the administrative structure and notably the appearance of what is known in Canada as the Crown Corporation, on which experienced business men gave part-time service as directors. This pragmatic device, analogous to the public corporation in Britain, had received much more extensive use since 1935, and after noting the establishment of the National Research Council as a Crown Corporation, out of the Advisory Council on Scientific and Industrial Research formed in 1916, Mr. Howe described a few examples including some of the twenty-eight Crown Corporations formed during the Second World War in the Department of Munitions and Supply, of which he became Minister in 1940. During and after the War the Department functioned directly as the sole procurement agency for the three Armed Services, and he thought that the Crown Corporation had proved itself to be an efficient device for enabling government to cope with certain new responsibilities thrust upon it by an advancing technology. Generally, he thought that the government should not enter into any business that is competitive with private industry, but certain responsibilities that could not be directed to private industry and certain other responsibilities which no private industry was prepared to undertake were most efficiently discharged through a Crown Corporation, nor did he think the device need be abandoned if private industry later entered the field. He also thought that the Crown Corporations had made an important contribution to better understanding between government and business, and in his twenty-two years experience it had been amply demonstrated that complete co-operation between government and business is a prerequisite of national prosperity. 